\title{
MITES (ACARI) OF SYCAMORE TREES IN EGYPT
}

\author{
YASSIN, E. M. A., SALWA M. E. SHOLLA AND M. A. MAHMOUD
}

Plant Protection Research Institute, ARC, Dokki, Giza

(Manuscript received 18 September 2008)

\begin{abstract}
This study determined the main mite species on sycamore trees, Ficus sycamorus L. from March 2006 to February 2008 and evaluated the possible relation between them. It was conducted in a plantation of 30 year old trees, about 15-20 m high, surrounded with crops as clover, cotton, bean and corn in the two seasons. Samples were taken monthly and consisted of twenty leaves, ten petioles and five terminal sections of twigs $(10 \mathrm{~cm})$ from 20 sycamore trees. All mites were separated and mounted for identification to family, genera and species. A total of 29 mite species for 24 genera in 14 families were found. Tydeidae was the family with the highest number of species (6), followed by Phytoseiidae (4 species). The highest abundnace levels of the mite pests recorded in case of family Tetranychidae (three species) followed by Tenuipalpidae (two species). The most abundant predators were Typhlodrompis swiriskii (Athias-Henriot.), Euseius scutalis (A. - H.) (Family: Phytoseiidae) and Pronematus ubiquitus McGrego (Family : Tydeidae) in the infested sycamore leaves. These predators could not prevent the increase of sycamore mite pests, Polyphagotarsonemus latus (Banks) (Family : Tarsonemidae), Eriophyes ficus Cotte (Family : Eriophyidae). However, their presence might have prevented an earlier increase and even higher levels of those mites.

Key words: Sycamore, Mites, Survey, Population
\end{abstract}

\section{INTRODUCTION}

Ficus Sycamorus (family, Moraceais) is a large deciduous tree that reaches 20-35 $\mathrm{m}$ tall at maturity, with a broad, domed deciduous crown. The genus Ficus is of great value for ecological and biological studies, due to its diversified system of biotic interactions with several groups of organisms (Compton et al., 1996). The name "sycamore" originally belongs to the fig species Ficus Sycamorus L. It is noted for its tolerance of wind, which makes it a popular tree for planting in cities along roads, also in fields for feeding on its fruits.

Sycamore trees are infested with different pests (mites, insects and others) during the different developmental stages. The most important mite pests associates with fig trees those belonging to Family Eriophyidae (fig mites).The fig mite infests bud scales and young leaves. Feeding causes a faint rustting of the leaves, generally in the interior portion of the canopy and may result in leaf drop and stunting of twigs. More importantly, this mite transifers the fig mosaic virus.. Also, the two spotted spider mites are consider as mite pests for sycamore trees and crops.. Heavy feeding causes browning of leaves and defoliation.. The aim of this work was to summarize the 
knowledge of mites found on sycamore trees in Egypt, giving a panorama of the development of this field and pointing the main species that occur on that plant.

\section{MATERIALS AND METHODS}

This survey was conducted in on about 30 years old sycamore trees, $15-20 \mathrm{~m}$ high scattered in plantations of annual crops as corn, cotton, bean, clover and wheat.. From March 2006 to Febrauary 2008, 6 trees were monthly sampled by taking random samples, a twig of about $20 \mathrm{~cm}$ long and with about 10-15 leaves of each tree. Samples were collected from the lower third part of the tree and sent to the laboratory where four random leaves were detached from each twig and the terminal section of the twig was cut to $10 \mathrm{~cm}$. The mites were then counted using a stereomicroscope. All mites of each tree were mounted on slides for subsequent identification of each species. When a large number of mites were belong to a single species was found (e.g. with high infestation levels of Orthotydeus californicus, only a sample of those mites were mounted.. To study the population fluctuation of the different mites, 20 leaves of sycamore plant were randomly taken every two weeks from Menofia Governorate during the same period. The collected mites were kept in Mite Collection of Acarology Department, Plant Protection Research Institute, A.R.C.

\section{RESULTS}

\section{A.) Incidence and survey study}

This study aimed to survey the different mites in different governorates in Egypt and their abundance. The survey was conducted during two years on sycamore trees from March 2006 to February 2008 and evaluated the possible relation between the different collected mites. The examined samples proved the occurrence of 29 different mites species belong to 24 genera in 14 families as follows :

\section{A-) Phytophagus mites}

The phytophagus mites in this study were represented by four familes, Tetranychidae (three species), Tetranychus urticae Koch, Eutetranychus orientalis (Klein) and Oligonychus mangiferus (Rahman \& Sapra), Tenuipalpidae (two species), Brevipalpus californicus (Banks) and Tenuipalpus sp., Tarsonemidae only one species, Polyphagotarsonemus latus (Banks) and Eriophyidae, (one species) Eriophyes ficus Cotte .The eriophyids mostly occurred on the lower surface of the newly leaves. Their were found on the lower surface of leaves were very high in case of Eriophyes ficus Cotte only upper surface, petioles and buds it migrate Table (1).

\section{B-) Predaceous mites}

The predaceous mites in this study were represented as five different families namely Bdellidae, one species (Spinibdella sp.), Cheyletidae, three species (Cheletogenes ornatus (C. \&F.), Cheyletus eruditus (Schrank) and Cheyletus 
malaccensis Oudemans, Camerobiidae, one species (Neophyllobius aegyptium Soliman and Zaher), Phytoseiidae, four species (Typhlodrompis swiriskii (A. - H.), Neoseiulus cyndoductylon (Shehata \& Zaher) and Pennaseius finitimus (Ribaga), Stigmaeidae, one species (Agistemus exertus Gonzalez) and Tydeidae, three species (Pronematus ubiquitus McGregor, P. rykei Meyer \& Rodriguez and Homeopronematus sp., Table (2).

\section{C-) Fungivorous and / or miscellaneous mites}

Eight different fungivorous and miscellaneous mites were investigated during this study. These were : two species in family Tarsonemidae (Tarsonemus setifer Ewing and Tarsonemus smithi Ewing), two species belong to family Acaridae Tyrophagus putrescentiae (schrank) and Acarus siro L., one species in the family Oribatidae (Siculopata sicula Berlese) while Tydeidae was represented by three different species (Orthotydeus lamb Bakeri, Orthotydeus californicus (Banks)nd Orthotydeus kochi Oudemans, Table (3).

\section{B.) Population dynamics}

Among the phytophagous mites, tetranychids, eriophyids and tenuipalpids were frequent throughout the period of study, but the tarsonemid mites were appeared from March to July and from November to February, Table (4). Tetranychidae, was rare in this study. Only 20 individuals were found during the first year and 22 individuals during the second 2007/2008, from June to November infesting the leaves only. The phytophagous mite, Brevipalpus californicus appeared infesting the newly leaves and twigs during the period of February to May with high numbers. Also, in the same eriophyids rapidly increased on leaves from to June, then declining afterwards. However, the population of the collected eriophyid mites was simply on twigs.

Phytoseiidae and Tydeidae genus (Pronmatus) were the most abundant of the families including the predominantly predatory species, which appeared during the all study counts without any disappearance. The highest population of the mites belonging to family Phytoseiidae appeared during September of the two years, then decreased, reaching its minimum level from February and March, after which it increased on sycamore leaves. On the other hand the population of these predatory mites was low on the twigs. The stigmaeid mites as predators appeared only on sycamore leaves during the period from August to October with accepted numbers. Two tydeids were both frequent and abundant throughout the study. Their highest levels were observed in June (first month of the observation period), September and February. The most abundant tydeid species were Orthotydeus californicus (miscellaneous mites) and Pronematus ubiquitus (predator mite). Other mites (Acaridae, Raphignathidae, Bdellidae, Cheyletidae and Euopodidae ) were frequent, but occurred always in very low population levels. 
$\mathrm{T} 1,2,3,4$ 


\section{DISCUSSION}

Studying the mites associated with sycamore trees in Egypt is very rare and this might be attributed to the scattering of these trees. In this study the different mites inhabiting leaves, twigs, and bark were be conducted during the two successive yearss $2006 / 2007$ and $2007 / 2008$. The survey proved the presence of mite species belonging to 24 genera in 14 different families. The most important phytophagous mites in this study were Polyphagotarsonemus latus (Family Tarsonemidae) and Eriophyes ficus Cotte (Family Eriophyidae). El-Halawany et al., 1986 recorded the phytophagous mites Rhyncaphytoptus ficifoliae and Eriophyes ficus, Tarsonemus smithi and T. fusari Gooreman and Tydeus californicus as miscellaneous mites and Phytoseius plumifer as a predator on fig trees in Qaluobia Governorate, Egypt. ElKhateeb 1998 collected the cunaxid mite Cunaxa setirostris from leaves and buds of ficus trees, Ficus sycamorus in El-Menofia Governorate. Also, Yassin (2004) collected Orthotydeus lambi (Baker) as new combination for the first time in Egypt inhabiting sycamore leaves at El-Menofia. Generally, the collected mites (phytophagus, predators and fungivorous were higher in their abundance in the second season 2007/2008 than those recorded in the first season 2006/2007 on the sycamore leaves. Most eriophyids are highly host specific, and their feeding often causes characteristic symptoms. This phenomenon was clearly observed during the course of this study on sycamore leaves. The tetranychid mites in this study did not cause any problems on sycamore leaves because their abundance species was very low comparison with other harmful mites, the number of taxa collected in this study showed the great mite diversity on sycamore trees in Egypt. The highest abundance of phytophagus mites in comparison with mites of other feeding habits is typical of ecosystem. In agro ecosystems, phytophagus species commonly reach high population levels due to lower diversity of natural enemies (Altieri et al., 2003). Tarsonemidae. species have been reported from the different Egyptian crops. Many tarsonemids are fungivorous, and some have interesting tritrophic associations with insects. The most important collected phytophagus mites in this study was Polyphagotarsonemus latus. In Egypt, P. latus capable of causing economic damage in greenhouses and nurseries. This destructive pest causes terminal leaves and flower buds to become malformed.. The highest species diversity of tydeids is probably due to the variable feeding habits of members of this family, that include phytophagous, predators, mycophagous and mites of other feeding habits. The variable feeding habits allow those mites to explore different types of microhabitats. Feres (2000) and Ferla \& Moraes (2002) also found a great diversity of tydeids in rubber tree plantations.. However, the high abundance of tydeids in this study, principally Orthotydeus californicus may be due to that tydeids seem to be by 
far most common in domatias and on twigs, which apparently were examined extensively in the present study. The highest abundance of eriophyids on the upper surface of the leaves was expected, as E. ficus, the predominant eriophyid in this study, is known to prefer this habitat (Vieira \& Gomes 1999, Ferla \& Moraes 2003). However, the occurrence of the eriophyid mite, $S$. petiolula mainly on the lower surface of sycamore leaves and on twigs contrasts with the observations of Feres (1998, 2000, 2001), who found this mite mostly on the petioles. The occurrence of tenuipalpids mostly on the lower surface of leaflets coincides with the results of other authors (Feres 2000, Pontier et al. 2001, Feres et al., 2002, Ferla \& Moraes 2002). Most tydeids were found in places where they could hide, as in domatias and in grooves, empty parasitized scales, in axils of petioles and in or underneath insect or spider webs on leaves or twigs. The increasing population levels of phytoseiids from March on coincided with the high population levels of tydeid mites especially the fungivores. However, these tydeid mites might be the best prey in this period. The combined actions of phytoseiids and other predatory mites could be one of the reasons for the reduction of the population of other harmful mites during the increasing time of these natural enemies. The relation of the tydeids with the phytoseiid predators is not very clear, and should be experimentally studied in the future. Marked abundance in tydeid levels on leaves on all sampling dates corresponded to discrete increases of those mites. The quick reduction in tydeid levels on twigs from June to February corresponded to very discrete decreases in phytoseiid and stigmaeid population levels. Also, these results suggest that phytoseiids did not significantly affect the populations of the dominant tydeid species in this study. It is not clear what caused the quick and considerable reduction of the tydeid population level on twigs and its maintenance at much lower level after September on that substrate. One possibility would be the preference of those mites for the leaflets as substrate, in this sense, the tydeids would have moved from twigs to the new leaves, as soon as those started to be produced by the plants from October.

\section{REFERENCES}

1. Altieri, M.A., E.N. Silva and C.I. Nicholls. 2003. O papel da biodiversidade no manejo de pragas. Ribeirão Preto, Editora Holos, 226 p.

2. Compton, S.G., J.T. Wiebes and C.C. Berg. 1996. The biology of fig trees and their associated animals. Journal of Biogeography 23:405-407.

3. El-Halawany, M. E., M. H. Kandeel and M. A. Rakha. 1986. Mites inhabiting deciduous fruit trees. Agric. Res. Rev., 64 (1) : 115-122. 
4. El-Khateeb, H. M. 1998. Life Tables of some predacious mites and their importance in biological control. Ph. D. Thesis, Fac. Agric. Cairo Univ. 183 pp.

5. Feres, R. J. F. 1998. Two new Phyllocoptine mites (Acari: Eriophyidae) from Hevea brasiliensis Muell. Arg. (Euphorbiaceae) from Brasil. Int. J. Acarol. 24: 6974.

6. Feres, R. J. F. 2000. Levantamento e observações naturalísticas da acarofauna (Acari, Arachnida) de seringueiras cultivadas (Hevea spp., Euphorbiaceae) no Brasil. Rev. Bras.Zool.17:157-173.

7. Feres, R. J. F. 2001. Ácaros eriofí́deos (Acari: Eriophyidae) em seringueira (Hevea brasiliensis Muell. Arg.: Euphorbiaceae) no Brasil, p.31-36. In L.A.N. de Sá \& G.J. de Moraes. Ácaros de importância quarentenária. Jaguariúna, Embrapa Meio Ambiente, 40p.

8. Feres, R. J. F., D. de C. Rossa Feres, R. D. Daud and R. S. Santos. 2002. Diversidade de ácaros (Acari, Arachnida) em seringueiras (Hevea brasiliensis Muell. Arg., Euphorbiaceae) na Região Noroeste do estado of São Paulo, Brasil. Rev. Bras. Zool. 19: 137-144.

9. Ferla, N. J. and G. J. de. Moraes. 2002. Ácaros (Arachnida, Acari) da seringueira (Hevea brasiliensis Muell. Arg.) no estado do Mato Grosso, Brasil. Rev. Bras. Zool. 19: 867-888.

10. Ferla, N. J. and G.J. de. Moraes. 2003. Ciclo biológico de Calacarus heveae Feres 1992 (Acari, Eriophyidae). Rev. Brasil. Entomol. 47: 399-402.

11. Pontier, K. J. B., G.J. de Moraes and S. Kreiter. 2001. Biology of Tenuipalpus heveae (Acari, Tenuipalpidae) on rubber tree leaves. Acarologia 41: 423427.

12. Vieira, M. R. and E. C. Gomes. 1999. Sintomas, desfolhamento e controle de Calacarus heveae Feres, 1992 (Acari, Eriophyidae) em seringueira (Hevea brasiliensis Muell. Arg.). Cult. Agron. 8: 39-52.

13. Wilkerson J. L., S. E. Webb. and J. L. Capinera. 2005. Vegetable Pests LL: AcariHemiptera-Orthoptera - Thysanoptera. UF/IFAS CD-ROM.SW 181.

14. Yassin, E. M. A. 2004. Studies on some tydeid mites in Egypt. Ph. D. Thesis, Fac. Sci., Cairo Univ., 319 pp. 
الأكاروسات المتواجدة على أشجار التين الجميزى في مصر

عصام محمد عبد السلام ياسين، سلوى محمودالسعيد شعلة، مصباح عبد الجواد محمود

معرد بحوث وقاية النباتات- مركز البحوث الزراعية- الدقي -جيزة

أجريت هذه الدراسة لتحديد أهم الاكاروسات المرتبطة بأنتجار التين الجميزى في مصر في الفترة من

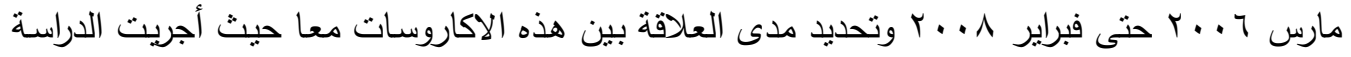

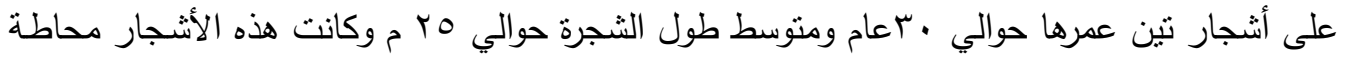
بدحاصيل مختلفة منل البرسيم والقطن والفول والذرة في مواسم مختلفة حيث كان حجم العينة ـ. ورقية

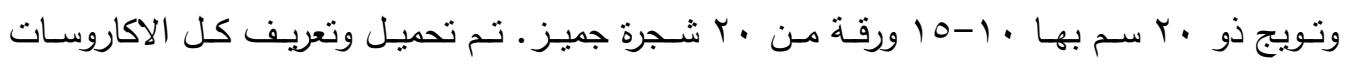

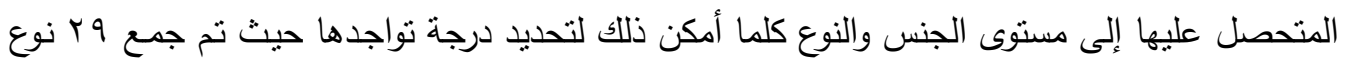
اكاروسى مختلف في ؟r جنس ينتموا إلى \& ا فصيلة مختلفة وكانت فصيلة Tydeidae هي أكثر

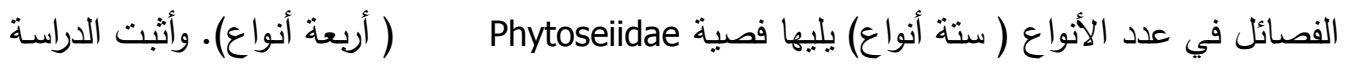
وجود (ثلاث) أنواع من الاكاروسات النباتية التغذية في فصيلة Tetranychidae أكثر الأنواع نواجدا

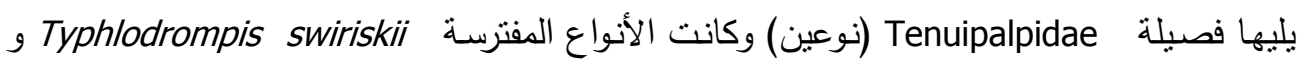

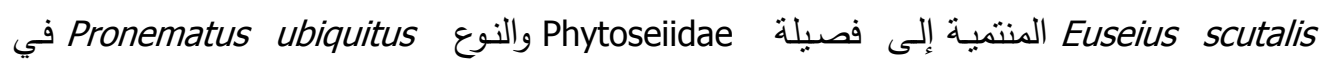
فصيلة Tydeidae هي أكثر الأنواع تواجدا على نباتات التين الجميزى. ولم يلاحظ أن الأنواع

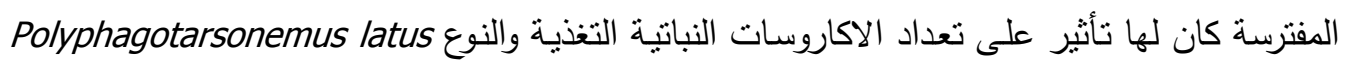
المنتمى لفصيلة Tarsonemidae و و Ehyllocoptruta oleivora و المنتمية لفصيلة وبدراسة التنبذب العددي للاكاروسات المتحصل عليها وجد أن الفصبلتين Eydiohyidae و

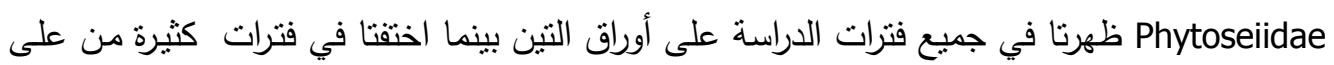

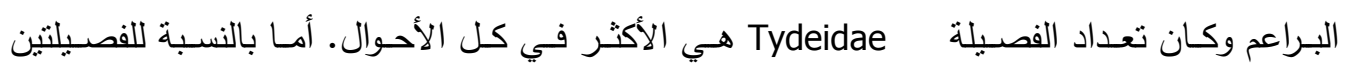
Tetranychidae 